\title{
Poor quality of life as a predictor of survival among thalassemia patients in Iran
}

\author{
Shahab Rezaeian \\ Research Center for Environmental Determinants of Health (RCEDH), Kermanshah University of Medical Sciences, Kermanshah, Iran
}

\section{Dear Editor,}

An Iranian study was recently published in your prestigious journal, in which the aim was to determine the association between health-promoting lifestyles and quality of life (QoL) among a sample of 389 adult beta-thalassemia major (TM) patients [1]. The findings of that study revealed an unacceptable level of QoL among the thalassemia patients, in accordance with another finding from an Iranian study $[2,3]$. So far, none of the studies conducted on the survival rate of patients with thalassemia $[4,5]$ have addressed the effect of QoL on survival in the discussion section.

We conducted a retrospective cohort study enrolling $704 \mathrm{TM}$ patients in 2016 in Shiraz, southern Iran. Our study aimed to identify changes in the survival rate of TM patients over the past two decades. Two different approaches, including a cohort analysis (Figure 1) and a period analysis (Table 1), were used to evaluate 20-year and 30-year survival rates and to compare changes in the survival trends in various time intervals between 1995 and 2016. The Cochran-Armitage test was used for trend analysis.

A downward trend was found in both the 20-year $(\mathrm{p}<0.001)$, and 30-year $(\mathrm{p}<0.001)$ survival rates of TM patients from 1995 to 2007, but an upward trend was found from 2007 through 2016 (Figure 1). The period analysis also indicated a downward trend in 20-year $(\mathrm{p}=0.002)$, and 30 -year $(\mathrm{p}=0.005)$ survival rates from 1995 to 2016 (Table 1).

\section{Correspondence: Shahab Rezaeian}

Research Center for Environmental Determinants of Health (RCEDH), Kermanshah University of Medical Sciences, Isar Square, Kermanshah 6719851351, Iran

E-mail: shahab.rezayan@gmail.com

Received: Jan 31, 2017 / Accepted: Mar 12, 2017 / Published: Mar 28, 2017

This article is available from: http://e-epih.org/

(c) This is an open-access article distributed under the terms of the Creative Commons Attribution License (http://creativecommons.org/licenses/by/4.0/), which permits unrestricted use, distribution, and reproduction in any medium, provided the original work is properly cited.

(C) 2017, Korean Society of Epidemiology
With these results in mind, the poor QoL reported among Iranian TM patients [1-3] could explain the downward trend in the survival rate of TM patients found in this study. The results of a study conducted to characterize health-related QoL (HRQoL) and its related factors found that chronic diseases, such as thalassemia, were a significant determinant of HRQoL [6]. Another important factor related to QoL and life satisfaction is self-rated health status, which has been studied in the general population [7] and among subjects with a chronic illness [8].

In conclusion, it is suggested that factors affecting QoL should be addressed in future studies to obtain important information for policymakers to improve the QoL in this population, thereby improving survival.

\section{ACKNOWLEDGEMENTS}

This work was extracted from the author's $\mathrm{PhD}$ thesis in Epidemiology. It received ethical approval and financial support from the Shiraz University of Medical Sciences (grant no. 94-7610).

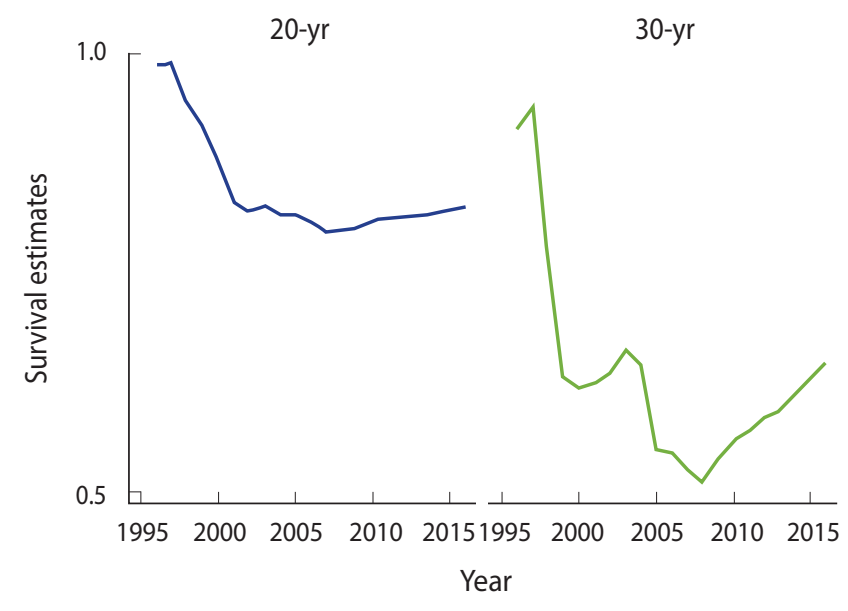

Figure 1. The 20-, and 30-year survival rates of thalassemia major patients obtained at various time intervals, Iran, 1995-2016. 
Table 1. Trends in the 20- and 30-year survival rates of thalassemia major patients by period analysis, Iran, 2016

\begin{tabular}{|c|c|c|c|c|c|}
\hline & \multicolumn{4}{|c|}{ Period } & \multirow{2}{*}{$p$-value } \\
\hline & $1995-2000$ & 2001-2005 & 2006-2010 & 2011-2016 & \\
\hline No. of subjects & 196 & 378 & 519 & 597 & - \\
\hline Deaths & 12 & 39 & 60 & 66 & - \\
\hline Mean probability of 20-year survival & 0.94 & 0.82 & 0.80 & 0.82 & 0.002 \\
\hline Mean probability of 30-year survival & 0.77 & 0.62 & 0.53 & 0.61 & 0.005 \\
\hline
\end{tabular}

\section{CONFLICT OF INTEREST}

The author has no conflicts of interest to declare for this study.

\section{ORCID}

Shahab Rezaeian: http://orcid.org/0000-0002-5094-5315

\section{REFERENCES}

1. Maheri A, Sadeghi R, Shojaeizadeh D, Tol A, Yaseri M, Ebrahimi M. Associations between a health-promoting lifestyle and quality of life among adults with beta-thalassemia major. Epidemiol Health 2016;38:e2016050.

2. Seyedifar M, Dorkoosh FA, Hamidieh AA, Naderi M, Karami H, Karimi M, et al. Health-related quality of life and health utility values in beta thalassemia major patients receiving different types of iron chelators in Iran. Int J Hematol Oncol Stem Cell Res 2016; 10:224-231.

3. Adib-Hajbaghery M, Ahmadi M, S P. Health related quality of life, depression, anxiety and stress in patients with beta-thalassemia major. Iran J Ped Hematol Oncol 2015;5:193-205.

4. Zamani R, Khazaei S, Rezaeian S. Survival analysis and its associated factors of beta thalassemia major in Hamadan province. Iran J Med Sci 2015;40:233-239.

5. Rajaeefard A, Hajipour M, Tabatabaee HR, Hassanzadeh J, Rezaeian S, Moradi Z, et al. Analysis of survival data in thalassemia patients in Shiraz, Iran. Epidemiol Health 2015;37:e2015031.

6. Karyani AK, Rashidian A, Sefiddashti SE, Sari AA. Self-reported health-related quality of life (HRQoL) and factors affecting HRQoL among individuals with health insurance in Iran. Epidemiol Health 2016;38:e2016046.

7. Daroudi R, Rashidian A, Zeraati H, Oliyaeemanesh A, Akbari Sari A. Life and health satisfaction in the adult population of Iran. Epidemiol Health 2016;38:e2016047.

8. Maharlouei N, Akbari M, Khabbaz Shirazy M, Yazdanpanah D, Lankarani KB. Factors associated with self-rated health status in Southwestern Iran: a population-based study. Public Health 2016; 140:179-185. 